$\begin{array}{ll} & \text { Etnográfica } \\ \text { etnográfica } & \text { Revista do Centro em Rede de Investigação em }\end{array}$

Antropologia

vol. $25(2) \mid 2021$

Vol. 25 (2)

\title{
Verbal art and the expression of the inexpressible: making sense of sensory experience
}

Arte verbal e a expressão do inexprimível: fazer sentido da experiência sensorial

\section{Regina F. Bendix}

\section{(2) OpenEdition}

\section{Journals}

Electronic version

URL: https://journals.openedition.org/etnografica/10493

DOI: 10.4000/etnografica.10493

ISSN: 2182-2891

\section{Publisher}

Centro em Rede de Investigação em Antropologia

Printed version

Number of pages: 513-538

ISSN: 0873-6561

\section{Electronic reference}

Regina F. Bendix, "Verbal art and the expression of the inexpressible: making sense of sensory experience", Etnográfica [Online], vol. 25 (2) | 2021, Online since 29 July 2021, connection on 19 January 2022. URL: http://journals.openedition.org/etnografica/10493 ; DOI: https://doi.org/10.4000/ etnografica. 10493

\section{(c) (1) (8)}

Etnográfica is licensed under a Creative Commons Attribution-NonCommercial 4.0 International License. 


\section{Verbal art and the expression of the inexpressible: making sense of sensory experience}

\section{Regina F. Bendix}

Sensory matters have crossed paths with cultural scholarship for more than two centuries and have, during the past two decades, received renewed attention in ethnological fields and various publishing ventures. The working of the senses in tandem with cognition facilitates the experience of pleasure and pain, fear and elation - but to what extent can (or should) this realm, situated between individual experience and social coding, be accessible to cultural research? The paper probes a number of examples and methodological issues in grasping experiences and sites of interaction where sensations are expressed in a culturally shared fashion and explores which areas of research may profit particularly from an expanded ethnographic sensibility.

KEYWORDS: senses, experience, ethnography, verbal art.

Arte verbal e a expressão do inexprimível: fazer sentido da experiência sensorial - As questões sensoriais têm vindo a cruzar-se com os estudos culturais por mais de dois séculos e, durante as duas últimas décadas, receberam atenção renovada por parte dos campos etnológicos e em vários projetos editoriais. É o funcionamento dos sentidos em conjunção com a cognição que permite a experiência do prazer e da dor, do medo e da exaltação - mas até que ponto pode (ou deve) aceder-se a este campo, situado entre a experiência individual e a codificação social, a partir da pesquisa cultural? Este artigo acompanha uma série de exemplos e questões metodológicas explorando experiências e locais de interação onde as sensações são expressas de forma culturalmente partilhada, procurando áreas de pesquisa específicas que possam beneficiar com uma sensibilidade etnográfica expandida.

PALAVRAS-CHAVE: sentidos, experiência, etnografia, arte verbal.

BENDIX, Regina (rbendix@gwdg.de) - Georg-August-University, Göttingen, Germany. 


\section{PREFACE: LEARNING TO TASTE}

Once a year, my colleagues Anna and Peter invite a group for a wine tasting. We work our way through about twenty-five wines, naturally only quaffing a small amount of each, and as we attempt to look knowledgeable while sipping, Anna reads out what she calls "wine poetry". An English example of this goes as follows:

"Attractive, soft and bright pink, [... a very interestingly delicate and complex bouquet with strawberry, rose petal, a touch of cotton candy, lime peel and some clove. The palate is generous, round and soft yet brisk and firm with wonderfully balanced acidity and richness. [...] Finishes with nice length and grip." I

Some of us gather around the table to joke about our failure to identify the hint of chocolate in the finish, and there is general amusement about just how many of the white wines are said to smell of "white flowers". Many present have participated in this party for twenty years or more, some are not speaking much but mark up the order sheet with exclamation points and minus signs. We relish yeasted bunt cake along with taste number 13, a crémant, before transitioning to the reds. As the evening progresses, the requests to hear the wine lyrics lessen, animated conversation increases and even though Anna keeps reminding us that tasting wine is hard work, the room erupts more often with laughter, the debates over which bottle is truly exquisite intensify. When Peter brings out the final bottle, a Gewurtztraminer, which Anna complements with the abominably stinky but miraculously matching Alsatian Munster cheese, bliss appears to be complete.

What is presented in this circle as an amusing, commodity-enhancing form of verbal art, to oenologists is a craft of appreciation: the translation of sensory experience of nose and palate into a form of prose that excels in precision and aims for praise. Even a mediocre wine is ennobled when accompanied by language assessing its sensory promise.

In my English-German dictionary, both flavour and aroma are translated as aroma. A differentiation into taste (Geschmack) and scent (Geruch) comes only in second place, making clear that in common parlance the intermingling of the two is common. "Hold your nose and you won't taste anything", is, after all, an insight that even a child in kindergarten discovers, generally with some amazement and disbelief. Thus, as convincing as wine prose may sound, the careful differentiation of the look, smell and taste of wine are learned and

1 From Wesportrivers wine descriptions, < http://www.westportrivers.com/wine_data/2002_rose. pdf $>$ (last access February 2006, no longer available). 
not innate, however careful and distinctive the canonical vocabulary seeks to be. What is analytically obvious is the linguistic recourse to aroma-memory, modelling synaesthesia: in tasting wine, we reach for a spectrum of identifiable tastes and smells which are to describe the uniqueness inherent to a new taste sensation. The eloquence of taste transformed into descriptions distinguishes the connoisseur, a growing group in Western economies with the spreading of luxury goods such as chocolate and coffee, as well as cigars. In everyday life, as depicted for instance in French belles lettres, more ebullient and less precise statements about wine, its perfume and its effects can be extracted. ${ }^{2}$

John Vankat, Ph.D., who administers the "Winepocketlist" and writes a column called "Straight Talk on Wine", reports a sobering experience. He conducted a blind test with inexperienced, somewhat experienced and experienced wine tasters, having them identify the wines on the basis of the wine descriptions. The most experienced wine tasters did the poorest - an experiment that in a more extensive and scholarly form was also carried out by three French scholars; they published their results in 2001 in the journal Brain and Language (Liberman 2004b). Dr. Vankat concluded:

"Perhaps it's related to each of us having different experiences with foods and drinks. When faced with a new wine, our senses tend to focus on what is familiar - it may be chocolate for me and earth for you - so we find different aromas and flavours in the same wine. [...] The next time you read about spice, earth, cherries, berries and chocolate in a wine, don't necessarily expect to find them. The fact that you don't is an expression of your personal experiences and preferences - and that's exactly what you must express to enhance your enjoyment of wine." ${ }^{3}$

Would such an assertion of individualism, an imperative of placing the personal above the communal ("what you must express!") go over well with the countless workshop and seminar leaders who seek to instill the "right way" to taste and thus create shared sensory experiences? For while even my friends Anna and Peter keep pointing out that tastes do differ, wine tasting discourse strives for agreement and scales from good to better which finds its expression in regional and international awards for better and best wines - and consumers seek to achieve distinction in schooling their palate, translating the experience

2 Kazuo Ogoura (2004), a francophone Japanese who held various diplomatic posts, sought to systematize such literary reflections according to states created by wine, functions of wine in social relations and the typification of special wines in their regional context.

3 The quote was drawn from the "Winepocketlist", < http://www.winepocketlist.com/straighttalkdetail.asp? ID $=5>$ (last access February 2006, no longer available). Since then, Vankat seems to have migrated to other online platforms and the Winepocketlist is, at the time of this writing, no longer accessible. 
into words and supporting in turn a sector of agriculture dependent precisely on such consumer striving.

The recent wealth of ethnographic and historical research on the role of the senses in culture has shown most convincing results in ethnographic and temporal specificity - both of which point to the flexibility of sensory orders over time and space. ${ }^{4}$ To expect an easy tool kit for exercises in intercultural communication is thus an unlikely outcome of sensory research. ${ }^{5}$ Rather, I see the dissolution of assumptions about bounded cultures as a reason for turning to the senses as a nexus between individual bodies and collectivities. Despite political and religious efforts to instrumentalize and perform clearly bounded cultural identities, life is lived in increasingly heterogeneous societies, permeated with technological sensory enhancements and barriers. Such a life permits individuals multiple identifications and, depending on class, gender, status and age, increasing options for self-realization. Such realization today very often takes the road of heightened sensory stimulation, as chroniclers and theorists of leisure society will attest (Lau 2000; Opaschowski 1991, 1993; Picard 2011).

The body and sensory perception constitute the membrane between the individual and society. We are surrounded by new health and body practices and associated products to cater to our senses, and hence it was and is high time to address the sensorium's workings through cultural analysis - though it does present us with methodological problems. Addressing the workings of the senses in physiological terms is more likely a task for neurosciences, but understanding the role of sensory perception within culture calls for ethnographic effort as well as the analysis of objects and documents - tasks cultural anthropologists and folklorists are supremely skilled at. An entry into this jungle via wine prose is not as roundabout a path as might appear. True, descriptive prose about wine has thus far hardly been granted entry into the canons of verbal art scholarship, though anthropological linguist Michael Silverstein

4 A recent exception is Veronica Strang's effort at asserting common or comparable meanings derived from "same" sensory experiences, the interaction with water (taken as the more or less invariable feature of the environment) in an English and an Australian aboriginal community. Very careful in her wording, she sees here a possibility for comparative work on shared human capability that might transcend the preponderance of ethnographic "particularity" without relapsing into the careless comparativism of the 19th and early 20th century (2005: 93-94). An excellent and concise summary of the anthropology of the senses is provided in Herzfeld's chapters on the senses and, naturally closely linked, aesthetics (2002: 241-253, 278-298); a chronicling of the fields' development is therefore not provided here. David Howes is the most prominent voice for what he himself terms the "sensory revolution" and has offered surveys of the pertinent scholarship in introductory passages both of his own book (2003) and works he has edited (1991: 3-22, 167-191; 2005).

5 Edward T. Hall's The Silent Language (1959) implied, in its focus on non-verbal dimensions of communication, sensory components; it rested firmly on a bounded concept of culture and remains foundational to some forms of training in intercultural communication. 
(2003, 2004) has made exemplary use of wine talk in a number of papers (2003, 2004) and worked with it extensively in his effort to develop a multicomponential lexicography (2006). Linguist Mark Liberman has written on wine talk in his not entirely serious language log (Liberman 2004a), Robert Ulin (1995) has deconstructed some of the aura and antiquity of the French wine growing industry and by association its speech community, and linguist Adrienne Lehrer (1983) has long followed the blossoming of wine talk. Wine talk is, however, only one type of specialized vocabulary surrounding sensory perception. The goal of the present article is to explore verbal art's role in articulating individual sensory experience and its cultural coding: what kind of categories of experience are constructed? how do they assist in marking status?

There are a number of thematic, discipline-specific as well as methodological boundaries that engagement with sensory matters brings about.

- The question of disenchantment is in my view the overarching one: how, and how far, can one probe without opening up such experiences and their "seat in life" (Köstlin 1995) for unwanted manipulation? This question naturally poses itself in much cultural research, making reflexivity, on the one hand, and ethics, on the other, two of the most important elements in ethnographic training. The domain of the senses would seem to be particularly vulnerable for (further) commoditization. ${ }^{6}$

- The sensual is at once deeply individual as well as cultural. It is connected to the specifics of our DNA and what use we learn to make of our given gifts. While ethnologists and folklorists have tended to focus on group expressions in the past, scholarship of the last two decades has increasingly recognized the deep interplay between individual and collective. Works such as Charles Taylor's Sources of the Self (1989) have shown the growing reflexive distance of the individual from the collective. Just as identity scholarship has shifted from assuming collective identities to examining individual actors in their identification choices, so research on the sensorium and its potential cultural patterning allow for an increased understanding of the relationship between individual and collective. The encouragement to wine lovers and budding oenologists poignantly illustrates the border zone that scholarship on sensory experience encounters: ${ }^{7}$ there are shared knowledges, cultural assumptions and traditional guidelines in the realm of the senses. For these,

6 Cyborg technologies are one such area; the advances sought to digitally transfer scents can also be mentioned, as well as the efforts to simply commoditize everyday scents and their attendant memories, as was explored by Dorothee Hemme (2008).

7 The notion of border zones I borrow from Roger Abrahams (2005) who has developed it in personal conversation, various public presentations and on the margins of his most recent book. 
a joint vocabulary, a verbal frame of reference, and a - however fleeting - historicity is generated and traditionalized. How much individual experience remains, into which the collective does not penetrate?

- The miraculous collaboration of senses and cognitive capabilities profoundly shapes human experience. As powerful communicators and interpreters between world, body and mind, the senses facilitate pre-emotive, bodily states that are essential for how we feel at a given moment. Pleasure and pain, fear or elation come about as we sense. Pleasure and pain, fear and elation are also markers of human frailty: just as we learn how to achieve or avoid them, others might use such knowledge to dominate us.

- Cultural research is, as Michael Herzfeld has pointed out, "primarily a verbal activity" (2002: 240). The "inadequacy of this Cartesian commitment" (ibid.) is increasingly recognized. But in methodological and representational terms, it is tough to address.

In the following, I would like to first backtrack and briefly situate the topic within excerpts of research history. I will then turn to four quite different areas to probe them for what they might yield for an approach intent on understanding verbal arts' role in capturing and traditionalizing, as well as culturally disciplining sensory experience - proverbial advice, tourism, interpersonal routines, and pain.

\section{GROUNDING}

In 1972, Natural History published "Seeing is believing", an essay by Alan Dundes (1980a [1972]). In a characteristically sweeping and punning style, he charted the evident preponderance of visual metaphor in American expressions and linked them, as in other essays he published at the time, to worldview (Dundes $1971 \mathrm{la} ; 197 \mathrm{lb}$ ). Worldview was of central concern at the time, and it was an interest, as Gregory Schrempp defined it, in the "basic postulates which cognitively and affectively orient humans toward themselves, other humans, the physical environment, indeed the cosmos" (1996: 21). To folklorists like Dundes, it offered a means to go beyond collecting endeavours, as well as beyond formal and structural analyses, and look instead at interpretations of expressive culture. This was Dundes's major interest throughout his career, and he openly stated as much in his first article collection, Interpreting Folklore (1980c). ${ }^{8}$ He chose Freud's psychoanalytic framework early on as an

8 Dundes' problems with the turn toward performance, his marginal interest in conducting research into the politics and history of folkloristics (1985) and his non-participation in later questions of agency and identity politics all reflect it. In his understanding, the folklorists' major tasks were [continues] 
overarching system for exploring latent meaning. I have my problems with Freud, but like Dundes recognize a need, in dealing with questions of sensual experience and its cultural elaboration, to focus on the continual interaction between an individual and the group(s) he or she interacts with. In 1977, Dundes offered his - frequently contested - definition of folk group: "The term 'folk' can refer to any group of people whatsoever who share at least one common factor. It does not matter what the linking factor is" (Dundes 1980b [1977]: 6). The definition put ethnic and national essentialisms in their place, or rather, Dundes placed folkloric processes and the linkages people create through them first.

In "Seeing is believing," Dundes used examples of folk speech to demonstrate that a constitutive component of the American worldview was to privilege the visual. As he was writing for a magazine presumably read by people interested in the workings of science, Dundes' second concern was to show why it was necessary for scholars to lay open the powerful factors within a worldview. "American science is not culture-free", he wrote, "no matter how devoutly American scientists wish that it were or think that it is" (1980a [1972]: 90). If scholars did not recognize that their methods were shaped by their worldview - in this case the favouring of data gained by sight - they would remain blind to all that was not processed through sight. "Surely a person's world is felt, smelled, tasted and heard as well", Dundes stated, so "this propensity for visual metaphorical categories may produce distortion in attempts to describe facets of American culture" (1980a [1972]: 91). And what, he worried, would happen if Americans turned their gaze upon other cultures or described "the features of the natural world?" (1980a [1972]: 91).

A great deal more than the unconscious privileging of one of the senses has since then been under scrutiny. But in 1972, both Dundes' push for reflecting the cultural bias in scholarship and his curiosity concerning sensory perception as well as the cognitive categories ordering them (1980a [1972]: 92) were relatively novel and intriguing. One can always, of course, turn to $18^{\text {th }}$ century discussions about aesthetics and find a profusion of writings about the senses, about language and perception, and about reception, though it was not called such at the time. ${ }^{9}$ In anthropologist Rhoda Métraux's chapter "Resonance in imagery", written in 1953, one can find an acknowledgment of the role the senses ought to have in fieldwork. David Howes has unearthed such early calls,

to show (1) the overabundance of folklore, and the generic process inherent to it in how all humans construct their world and make it meaningful, and (2) finding the latent meanings of folklore, and relating them to an overarching organizational system.

9 For a taste of those debates as well as a consideration for why the sensorium disappeared from folkloristic and anthropological purview, cf. Bendix (2000); a thorough examination of the early, especially German discussion can be found in Naumann-Beyer (2003). 
particularly for anthropology (Howes 2003: 10), but those who turned to such questions later did not acknowledge Dundes' essay as a forerunner.

Chronicling the power of the enlightened eye would become a crucial element of postcolonial deconstruction and analyses of modern leisure (Jay 1994; Pratt 1992; Urry 1990). It also figured prominently in the turn toward recovering the sensorium in anthropology (Kamper and Wulf 1984; Classen 1991; Howes 2003: 17-32). And both the writing culture movement within anthropology, and the newer interest in science and technology studies have exposed sources of cultural, gendered and personal bias in scholarly work. James Clifford's opening essay in Writing Culture even muses on the absence of the ethnographer's ear in ethnographic writing (1986: 12). However, the subsequent debate over the "crisis of representation" in the field was more heavily concerned with subjective entanglements (or was, at the very least, diminished by the accusation of having done so) and rarely turned toward reflection of sensory modalities in ethnographic methods.

Dundes pushed open an intriguing door into what David Howes some thirty-one years later would entitle Sensual Relations (Howes 2003). With few and limited exceptions, folklorists and anthropologists took their time to walk through this door, working instead on what are admittedly necessary methodological issues, or producing circumscribed case studies. ${ }^{10}$ However, there are more intriguing issues when contemplating the place of the sensorium in culture and cultural research. A person likely experiences his or her world through all the senses. A good part of this experience appears at first glance completely idiosyncratic - residing between an individual, the sensory shrewdness and refinement allowed by her genetic make-up, and her particular "world". However, just as "individuals" carry "culture" within them through processes of enculturation and socialization, so individuals carry "nature" within them in the form of DNA transmission. Nature and culture are not oppositional categories, rather, both are constituted and intertwined through humans' use and interpretation of their biological and cognitive resources. Sensory perception plays a crucial role in this process. Yet what role does traditionalized categorization play in the sensory ordering and experiencing of the world - as opposed to or rather in combination with neurological pathways and cognitive processes? How might it be possible, through such questioning, to re-establish "culture" as a significant analytic category without relapsing into which aspects of this can be addressed with the tools available to a student of culture? With or without interdisciplinary openings, and with the barriers of our verbal over-determination well in mind, one needs to still ask what kinds of

10 Simon Bronner sought to correct Dundes's perception, making a plea for the power of haptic experience, in particular for material culture studies (1982, foundational also for his later booklength study Grasping Things, 1986). 
questions can be opened up for contemplation through an inclusion of the powers of the sensorium.

We are, by training, not equipped to look into a person's mind and body to uncover how he or she senses. We can, however, work on our mind, body and senses to expand our ethnographic options - an issue that will remain marginal in this paper, as this has seen some stimulating thinking in recent years. ${ }^{11}$ There are, one might argue, border zones to be explored also in ethnographic comportment, as methodological training has generally excluded the pursuit of matters residing in areas that are or were social taboo zones. As an example one might mention the wide spread cultural practice of experiencing as well as actively seeking sensory overstimulation. Sensory disorders and overload, sensory deprivation and compensation would all fall into this realm and are certainly a deep part of human experience. ${ }^{12}$ We can also examine discourses about sensory experience, which reside, among other places, in verbal art. Whether one looks at the vocabulary for training the oenological taste experience, or more broadly at proverbial views and advice on sensory experience, one uncovers - and this would be the thesis accompanying my exploration here - a collective effort to guide, channel or discipline the body's inchoate and potentially dangerously boundless, sensory experience. The notion of "collective" requires greater inquiry: to what extent can one speak here of a political effort to produce docile bodies that reproduce the sensory regime? Group and subgroup discourses about sensory experience are arguably an effort to reach an individual at his or her most intimate, culturally least accessible, and thus perhaps also closed-off level. This need not necessarily be regarded as a negative, "discipline and punish" mechanism. The play of discourses in wielding power is not unidirectional (Foucault 1991: 122). As I will try to show - and as the wine tasting language already demonstrated - there is also an enabling thrust in such discourse. It may assist an individual in developing the sensory

11 Deirdre Sklar has surely aided by her dance background and specialization in dance ethnography, developed strategies involving the body and sensorium of the ethnographer in a conscious fashion so as to transcend the focus on the ethnographic gaze (Sklar 1994); more recently she has thought to take this consciousness into the writing process (Sklar 2005). David Howes's section "taking leave of our senses" in his major study includes some attention to questions of method, though he interweaves them with his general critique of the loss of sensory attention in anthropological research (Howes 2003: 1-28). My own summaries of methodological matters are developed in Bendix (2006); particularly relevant are, from my experience, the differential sensory capacities an individual has depending on a given biographical moment, also known as aging. Furthermore, the use of various technical tools to assist in participant observation have an impact on the capacity for what Sklar calls kinesthetic empathy.

12 In personal communication Valdimar Hafstein pointed out these potentials, starting with the Icelandic lexicon where the word for sensing or perception is "skynjun" whereas the word for hallucination is "ofskynjun", i.e. "overperception". The presence of such vocabulary is evidence of the cultural anchoring of a phenomenon and hence, in terms of disciplinary curiosity, a realm to be researched. 
acuity necessary for work and life, and it may also assist in the unfolding of connoisseurship and thus unleash individual potential. It may, therefore, not only be a matter of creating further distinctions - that perennial effort to set oneself apart in terms of class, gender, race, age or other markers (Bourdieu 1984).

My suggested approach is related to some strands within the anthropological research on emotion (Abu-Lughod and Lutz 1990; Wulff 2007), though I am not venturing as far as Birgitt Röttger-Rössler opts to do in her work on emotion as a bio-cultural process (Röttger-Rössler 2002, 2004). The bridge between senses and emotion is one that might fruitfully be developed; I am not crossing that bridge here, but am drawing from Don Brenneis's recent suggestions regarding the potential of combining the two areas. He pointed out that "the language upon which we frequently rely for relating sensory experience is that of feeling, of the emotions", and posited a shared vocabulary that "links affect with the effects of sensory phenomena". Drawing on Robert Levy's distinction of "hypercognized" and "hypocognized" emotions, Brenneis suggested a distinction between "highly elaborated, conversationally and ritually salient ways of sensing" and "less ostensibly mediated dimensions of sensory experience" (Brenneis 2005: 142-143).

In the following, I briefly explore a number of areas of sensation, beginning with domains where commenting on ways of sensing is highly elaborated to areas where such elaboration is foregone in favour of alternate forms of communication - or to no communication at all: there are limits to verbal art just as there are limits, as Brigitta Schmidt-Lauber (2004) has argued, to narration.

BEWARE OR BE AWARE OF THE SENSES:

PROVERBIAL WISDOM AND ITS LIMITATIONS

When moved to describe sensual experiences, adverbs are sometimes used that indicate the impossibility of putting into words just how an experience feels "indescribably beautiful", "unspeakably painful", "inexpressibly tasty". These are admissions that the linguistic categories available to communicate the sensual dimensions of ordinary and extraordinary daily living are simply insufficient. How is one to describe that nasty ache, new and yet so much in the way of pursuing one's daily chores? It is certainly a great deal more difficult than expressing to a new love the assembly of somatic sensations brought on by the attraction, or delving into Shakespearean metaphor to invoke the state of one's heart - induced not least by the sensual perception of such a love interest.

Collective advice on handling the senses and the considerable part they play in daily interaction is something proverbs, proverbial phrases or folk speech more generally contribute to - though just as often, the senses are proverbially invoked for metaphoric purposes. I will not attempt to follow-up on the ques- 
tion of a group-based preference for relying on one particular sense as did Dundes in "Seeing is believing" and Sharif Kanaana and Ibrahim Muhawi in a paper responding to Dundes (Kanaana 2005). Such an endeavor would require lengthy ethnographic immersion, and even then I am not sure one could come up with a telling result. Collections of proverbial materials show contradictions, as they serve as rhetorical devices for people of divergent opinions, and are traditionalized and deployed again in still other, more differentiated situations (Yankah 1989).

Estonian paremiologist Arvo Krikmann has made available a digital database of Estonian proverbs collected in the field and searchable not only in Estonian but also in German, hence I will explore some proverbial evidence on handling the senses in Estonian. ${ }^{13}$ One could do this equally well with other sets: a similar option is available in CD-ROM format, namely Karl Friedrich Wilhelm Wander's Deutsches Sprichwörter Lexikon (2001), published from 1867 to 1880 . In fact, a parallel check shows considerable overlap. But the Estonian collection is based on much more recent and ongoing field collecting. On Krikmann's advice, I entered vocabulary terms such as "eye", "mouth", "taste", "smell", "scent", "stench" and so forth, and ended up with a wealth of examples. A few examples will suffice to stimulate some reflection on the effort evident in proverbs to depict and comment on the working of the senses and/or establish a moral-metaphoric linkage between proper or improper sense-management, and social station or character. I do not want to make some kind of universal statement; the admittedly unsystematically selected sample is Estonian, and while some examples have analogues in other languages, others do not. I simply want to show the possibilities inherent in such materials: they allow one to probe human awareness of sensory workings and putting them into metaphoric form. ${ }^{14}$

The proverbs also show attempts to contain or streamline sensual wants and wishes, and in the process, they communicate to fellow human beings how they might - or should - handle their sensorium in communal situations. "Eye" and "mouth" provided the most examples, whereby mouth is most frequently linked to speech, not taste.

13 Many thanks go to Ülo Valk and Arvo Krikmann for guiding me to this resource. All Estonian materials are drawn from < http://haldjas.folklore.ee/rl/date/robotid/leht2s.html > (last access June 2021).

14 Cognitive scientists like Mark Turner would argue that we have no choice but to express ourselves metaphorically and that our metaphors must come from the senses and the body (Turner 1996). While the thinking of Turner and others is intriguing and illuminating, I am observing with some chagrin the reemergence of questions of "origin" that find their way back also into literary and folkloristic thinking. Whether one searches for origins in the distant past as diachronic paradigms of the $19^{\text {th }}$ and early $20^{\text {th }}$ century did, in formalist and structuralist paradigms or in neurolinguistic thinking, origin matters do not help us understand how such human capacities are put to use. 
"If there is a child in the house, one needs not one but nine eyes" or, abbreviated and collected very frequently: "Many children, broadly-ranging eyes". ${ }^{15}$ Raising children, this proverb communicates, requires multiplying one's sensory awareness to a heightened state. One will not find such a simple adage in the (overly) conscientious parenting handbooks. Yet it is an observation that a parent given to worry about harm or mischief will immediately identify with, perhaps taking some pride in occasionally succeeding in just this eye-opening feat. In terms of cultural analysis, the proverb opens one's mind to new ethnographic dimensions in fieldwork - particularly in the culturally expected broadened capabilities of a person turning parent.

Similarly descriptive and immediately understandable are the following examples: "Love puts twenty pairs of eyes in the head", "Fear has big eyes", and "Where there is a sick person, there is a hand, where there is love, there is an eye" - that is, love is (at first at least) distant and shy, relying on vision to ogle the loved one, but the sense of touch, the immediate bodily involvement, is necessary if a sick person is to be cared for. ${ }^{16}$

The following two proverbs comment on sensory selfishness which is subject precisely to the kind of cultural disciplining mentioned earlier: "One's own mouth is nearer than the mouth of the child" or "One's mouth is always the nearest". The disciplining is especially evident in the proverb: "One's own mouth must keep to moderation". ${ }^{17}$ Such disciplining and adhering to premonitions then gives rise to proverbs such as "He who eats when his stomach is empty will savour the food the best". ${ }^{18}$ Frugality is seen as keeping the sense of taste in check; taste buds will be thrilled with little if one has not spoiled them before, also expressed in: "He who takes every possible walk will savour all types of berries". ${ }^{19}$

Of course these are proverbs customary of a time and place of rural poverty and reliance on local rather than global food markets. Estonian forests and swamps were indeed likely to produce an abundance of berries in summer, but it was those who worked hard and had little who traditionally supplemented their diet by gathering berries. Thus this too is a proverb assuming that nutritional deprivation teaches the taste buds to relish sparse resources. At present,

15 All cited proverbs come from the Estonian proverb site, cf. footnote 14. Here proverb nr. 5461, "Kui laps majas, peab üheksa silma ühe asemel olema"; and nr. 5573, "Palju lapsi, laiad silmad".

16 Estonian originals: nr. 375, "Armastusel om katskümmend paari silmi pään”; nr. 1293, "Hirmul on suured silmad"; and nr. 753, "Kus haige on, seäl on käsi; kus arm on, seäl on silm".

17 Estonian originals: nr. 7964, "Oma suu om ikki lähemäl ku latse suu"; nr. 7965, "Oma suu on ikka köige ligemal"; and nr. 8028 "Umah suuh vaja möödi olla".

18 Estonian original: nr. 4783, "Kui kõht tühi, siis maitseb söök kõige parem". An Icelandic proverb expressing the same sentiment is: "Рað er svöngum sætt sem er söddum óætt", which translates into "For the hungry what is sweet, the sated would not eat" (courtesy of Valdimar Hafstein).

19 Estonian original: nr. 4824, "Kes keik kõnnid kõnnib, see keik marjad maitseb". 
in times of greater affluence, one recognizes that taste buds do just fine with abundance, but the approach today is one of teaching and market-based connoisseurship - as evident in the wine tasting and seminars this article began with.

"Honey in the mouth, bile in the heart" is metaphoric in thrust, but a puritan view of sensory management also shines through this proverb. Speaking with a sweet or mellifluous voice carries a negative connotation, presumably according greater honesty to the person who speaks gruffly. ${ }^{20}$ And as indicated above, there is a proverb to express an alternate point of view: "What is beautiful for the ear to hear is lovely to see for the eye". ${ }^{21}$ The sense of hearing appears frequently in association with the capacity to negotiate or to ignore - "To hear bad things one has to have thick ears" 22 - or to evaluate relationships: "Listening up close, the smithy does not sound as brightly as when you hear it from afar". ${ }^{23}$ Classic for its disciplining thrust is "He who does not want to hear will have to feel". ${ }^{24}$ This is also a proverb that explains the enculturating expectation that individuals will make use of their sensory capacities in conformity with social norms. Simultaneously, the physio-neurological foundation of sensory perception is affirmed: failure to hear "correctly" or to listen at all will be punished corporeally and administered through the sense of touch. "Feeling" in this context is clearly communicated to be a lower but also more effective sense: if a person (very likely a child) has not "heard" (not paid attention or disregarded the message), then he or she apparently does not know how to handle audible, complex communication properly and will have to suffer simple physical reprimand.

Most proverb collections are older and thus lack the kind of contextual data one would need to properly understand their meaning within a given sequence of actions. They are repositories of not always immediately evident commentary, advice or guidance on managing sensual perception. Although present-day ethnographic perspectives will find such compendia lacking, they nonetheless offer insight on the cultural imprint that placed upon the sensorium.

\section{TRAVEL, EXCITEMENT, CONTEMPLATION}

One can turn to a field of cultural research seemingly very far from paremiology and discover in tourism a similar guiding, if not disciplining, of sensory experience. Nelson Graburn has suggested that tourism scholars might profit from going beyond the critique of "occularcentrism" to focus more on 
the physical, bodily-focused and hence multi-sensory cravings tourists seek to fulfill (Graburn 2001: 82). All the interesting research on the tourist gaze aside (cf. Urry 1990), tourism has always been strongly linked to much more than visual sensory experience. "Taking the waters,", bathing in the sea, and searching for healing mountain air were $19^{\text {th }}$ century reasons among the upper classes to leave home for a spa; healing and prophylaxis were the goal, but travel reports before, during and after that era acknowledge the profound affect such experiences had, as the senses were challenged to cognitively integrate new sensations which in turn were to be culturally contextualized. Fiction is a good source for tracing the impact of such experiences. To just name one example: E. M. Foresters 1908 novel Room with a View paid attention to the sensorial enchantment as well as confusion and revulsion of British travellers visiting Florence. Judi Dench's portrayal of novelist Eleanor Lavish in the 1985 film rendition by Merchant \& Ivory remains memorable not least because she revelled in observing the sensory affect the Toscana had on unsuspecting Brits. She also enacted the sensory pleasure of inhaling a city air so entirely different from that of England - and Maggie Smith as Cousin Charlotte showed the angst of anything foreign, including smells, entering her very British old maid's body.

The language of tourism advertisement is rife with sensory suggestions, and what is not said in words is expressed in alluring visuals. Their appeal to us and the reasons for why we ought to respond to this appeal have long been internalized - but it is profitable to look back at earlier forms. Early instructions for how to travel were gathered under the title "the art of travel" (Apodemik) and were, at least in Germany, an essential part of an $18^{\text {th }}$ century university curriculum (Stagl 2006). They gave their readers not only practical advice and information on landscape, cities and people; they also strove to instruct them on how to perceive. The educated person was to travel in order to accumulate not simply knowledge but experience that would refine the character in just the way required for his or her elevated station in life. While visual experience was an important component in the enlargement of personality, practicing the art of travel was meant to refine embodied experience in toto, and - as with the nudging of proverbs - handbooks in the art of travel spelled out how this was meant to work.

Cultural variants of this practice should be interesting to pursue. A colleague in sinology, Michael Lackner, has accumulated a collection of photographs of "guidance signs" he has seen posted at sites deemed worthy of a traveller's attention. He calls them the "deictic imperative of East Asia", as they spell out for the visitor how they are to respond to what they see before them. ${ }^{25}$ At Hangzhou's popular West Lake, for example, one can find a sign in

25 The following examples were collected by John Bendix during a joint conference visit in Shanghai with Michael Lackner, December 2004. 
English introducing the visitor to "A Bamboo Path Leading to Serenity", the text stating: "The spot here reminds one of a poetic sense". More confusingly, a sign in one of Suzhou's gardens reads: "Civilized Behaviour of Tourists is another Bright Scenery", though another sign on a nearby slope states: "Cherishing Grasses and Flowers is as Same as Cherishing the Life", a sentiment perhaps not unique to Chinese culture. The appropriate sensual training of the individual within a given cultural, historical, and religious context is the issue here, and such signs reflect the interlocked workings of disciplining and enabling.

\section{INTERPERSONAL INTIMACY AND THE LIMITS OF VERBAL ART: TACITLY SHARED SENSORY KNOWLEDGE}

At a dinner on the occasion of awarding the most renowned prize in culinary arts in Germany, the two hundred guests were seated at round tables of eight to ten each in Stuttgart castle. The seven-course meal was prepared by seven cooks, each of whom had earned one star or more in the prestigious Michelin Guide. The thank you speech of the Catalan prize winner, Ferran Adrià, had long passed. The guests from the elevated restaurant and hotel scene, along with a number of well-known vintners and high ranking politicians, were conversing quietly as course number four was served. After a few bites in silence, the gentleman next to me looked up and exclaimed in ecstatic tones to no one in particular: "It is the sauce! I have to once again say: it is the sauce!" With a look of utter bliss he returned to the remaining morsels on his plate. He had just verbalized what he felt ought to be a shared gustatory insight, the delectable power of a sauce, this sauce, to transform a piece of fish into a heavenly experience. This breakthrough into words was, judging by the silent nods of approval around the table, hardly necessary. One was partaking of a near-unbearable pleasure - it was a palpable feeling in the hall throughout the meal, though this was the only instance where a direct expression of sensual pleasure was heard that went beyond the "this was really lovely, excellent, wonderful". ${ }^{26}$ The tacit knowledge of what we were jointly engaged in did not require words; manners are such that overly explicit description of the gustatory pleasure would have been inappropriate, and yet the shared knowledge of the sensory bliss - and the amount of attention it drew away from one's capacity to converse - was palpable.

In his study Cultural Intimacy (1997), Michael Herzfeld described how a group - in this case the Greek nation-state - is aware of shared cultural

26 As a member of the advisory board of the German Academy of Culinary Studies I had the opportunity to participate in this event in December 2005, available at < http://www.kulinaristik.de/witzigmann.php > (last access June 2021). 
practices but seeks to hide them, or keep them esoteric, to use William Jansen's old labelling device "esoteric-exoteric" for intergroup dynamics (1959). Differential identification is here not used to generate folklore, as Bauman (1971) argued, but certain traditionalized traits are dissimulated in order to save face in intercultural encounters. I thus suggest "interpersonal intimacy" here not as an euphemism for sex. ${ }^{27}$ Rather, I seek to label the presupposition that there is shared knowledge regarding the sensorium's hold on life experience, though it is experience that is not usually talked about. What is shared of this knowledge is fragmented and limited, and that, too, is known. A child turning to tickle another's feet tests by asking: "are you ticklish?" He or she is using but one of many traditionalized routines to explore another's sensitivities and bodily individuality. Other such tests that come to mind are breathing down someone's neck unexpectedly or stroking the skin with a blade of grass and see whether goose bumps develop, and clapping loudly or otherwise creating an unexpected sound to test audio-sensitivity. Plants known to have a stinging effect on skin (e.g. nettles or opened rosehips) are used to test one another's toughness, just as cold and slimy substances are well-loved for testing someone's resistance to the horror of touching the unknown. Knowing whether someone else is indeed ticklish, whether a certain sound is particularly pleasing or, conversely, horrendous, whether a taste sensation creates a gag-effect or is addictive, whether a given texture makes someone break out in hives or a scent brings on irrepressible memories - these are all means to concretize a more abstractly assumed interpersonal intimacy. The discovered characteristics may be idiosyncratic, or they may be the result of familial or group elaboration and traditionalizing. Just as knowledge of mythological Siegfried's unprotected spot or Achilles's heel entails danger, knowing another's sensory weaknesses entails power. The unexpressed sensory awareness inscribed in an individual body becomes penetrable to social handling, to good or ill effect.

In a brief essay in a special journal issue edited by Orvar Löfgren and Richard Wilk entitled "Uncharted territories: an experiment in finding missing cultural processes", I labelled the phenomenon I am seeking to describe here "the cream effect" (Bendix 2005a). Whether it refers to the purring satisfaction achieved from tasting a delectable sauce or the high experienced from burying one's nose in fragrant flowers, the cream effect is a tool at one's disposal to enhance a moment in time. An early $21^{\text {st }}$ century person living in peaceful and economically well-off circumstances will have little to put between herself and the lure of the cream effect - other than the struggle against a variety of disciplining regimes, remnants of puritanical self-denial and an abundance of

27 Sexuality is a realm of human experience where the sensory and its cultural coding are deeply entangled. I have bracketed this realm out of this talk, as ethnographic inquiry always contains the danger of disenchantment, but am certainly aware that anyone reading it will be thinking about it. 
medical and gendered knowledge concerning the known, or believed, literal (if not even metaphorical) effect of indulging in cream. "Two salient features of the cream effect (are) [...] (1) its almost anti-Cartesian logic (I sense, therefore I am pleased); (2) its availability both for an individual's self-gratification and for manipulative use in human interaction" (Bendix 2005a: 15).

It is this "manipulative" possibility that is perhaps most easily accessible through verbal art. It shows sensual layers within interaction that are missing from the kind of analysis modeled by, for instance, sociologist Erving Goffman. There are examples of it we are all familiar with, where instead of "manipulation", one would rather speak of enchantment. A performer of narratives, for instance, offers such pleasures doubly. With her narrating voice, she can seemingly transport her listeners temporarily to a world of story (Sturm 2002), achieving considerably more through her vocal art than what Austin attributed to the word in speech act theory. ${ }^{28}$ By her vocal marking of different characters, a narrator relies and comments on her listeners' capacities to categorize vocal registers as those of men or women, children or old people, as voices sounding sincere, or as voices faking affection or friendliness. Such affecting presence - in a connotation expanded from Robert Plant Armstrong's meaning (Armstrong 1971) - potentially deployed in performance on the entire sensorium, should open possibilities for the study of reception, an aspect that has been mostly implied but not much focused on in performance studies (Bendix 2004). The power of listening and listeners' efforts to actively shape their listening has been most prominently examined in work on music and listening (e.g. Bull 2000). But it is there in every kind of sensory experience, and it is understood and used far better in the food and wellness industry than in cultural research..$^{29}$

Finally, there is the dark variant of the manipulative potential of interpersonal intimacy that I am skirting, but that we innately understand from the pictures of Abu Ghreib, Guantanamo Bay and countless other instances of brutality, crime, imprisonment and torture. There is probably no better argument to be made for including the sensorium in a cultural understanding of human agency than pointing to the sensory deprivation employed in imprisonment and torture. Here, the immense vulnerability resulting from interpersonal intimacy offends the witness's sense of human dignity and makes one wish that a victim were able to dissimulate so as not to be tortured where it hurts the most. These are then hypocognized practices, set into words that would be banned as illegal, and yet they are subject to cultural patterning and

28 In Bendix (2005b) an effort is made to explore "voice" more extensively as a crucial element in narrative research.

29 Brian Moeran's study of perfume marketing in Japan makes a step in this direction (2005). Agricultural economics, for instance, works with sensory laboratories to fully grasp gustatory preferences and assist producers to develop and perfect their products accordingly. 
figure prominently in the imagination. ${ }^{30}$ The darkness of this line of research is two-pronged, for aside from the pang of empathy at the thought of present-day torture victims, there is also the element of voyeurism, the curiosity about inflicting pain or having pain inflicted upon oneself. Some contributions in David Howes Sensual Culture Reader (2005: 248-354) are placed under the heading "aesthetization of everyday life," and here, too, the perfecting of sense perception, as envisioned already by $18^{\text {th }}$ century aesthetician Alexander Baumgarten (1983 [1750-58]), ranges across the sensorium, including the privileged as much as the tabooed. A history teacher I know calls the increase of torture scenes and museums in the living history movement evidence of the sado-masochistic fascinations of the present. The link between tourism and sensory curiosity and thrill becomes evident in this realm as well: some tourists seek out sites of horror, cruelty, and suffering - and some engage in purifying suffering themselves, as manifest in the upsurge of engaging in lengthy pilgrimages oneself instead of simply visiting pilgrimage sites. Tourism scholarship has gathered such trends under the heading "dark tourism", choosing a visual connotation for what is a complex bundle of memory, history, and sensory expectations offered to tourists (Lennon and Foley 2000; Skinner 2012). Probing what tourists actually sense and feel - as opposed to think about - when visiting such sites is thus far not researched very deeply, not least because tourists, much like anthropologists, will be logo-centric in their responses. ${ }^{31}$

\section{LURING THE INEXPRESSIBLE INTO THE VERBAL}

There are other kinds of pain that must be lured from the hypocognized into the expressible realm. Just as the oenological virtuosi I began with, healing professionals, no matter in which cultural setting, require descriptions of pain suffered in order to proceed to diagnosis and treatment. ${ }^{32}$ There are familial and cultural norms for how pain may be vocalized or shown. My mother taught me repeatedly that women in my family are not to show weakness during birth; as a very caring nurse, she did not show her disdain for those who cried about minor injuries, but at the lunch table she would lament about how excessive moaning and crying impeded the work of medical professionals. She worked

30 Consider the scene in the 2005 movie Syriana where George Clooney's character faces a torturer who enumerates possible torture options, including "the Chinese water chamber" - and the viewer instantly imagines not the material contours of the chamber but the sensory pain this form of torture would entail.

31 For a case study on Holocaust site visits for Israeli youth, cf. Feldman (2008).

32 If I am not, in the following, reviewing the scholarship on pain in cross-cultural perspective in medical anthropology, it does not mean that I am not aware of its existence. The present paper is intended as an exploration focused on ways in which cultural scholarship might achieve a more overarching sensory awareness. 
best in a kind of pact with the suffering person: her capacity for caring and efficient touch increased with a patient who could keep his pain in check. Some Swiss doctors assume that the Alps draw a dividing line between those living to their north who are tough in handling pain, and southerners who have a low tolerance for even "minute" pain. Doctors in the southern part of Switzerland instead draw that line at the Apennine Mountains, sure that people in Rome and further south are of the more sniveling disposition...

This is a realm, then, where sensory experience and its vocal expression are talked about. Some sources of pain are easy to identify. It is the invisible ones that need, at least in some medical systems, to be differentiated through conversation. This is how one surgeon describes it: "What a doctor offers at the bedside of a patient suffering from pain is indeed words, a whole palette of adjectives with which one might characterize pain, linking them in addition to the bodily topography". ${ }^{33}$ From this palette (note the term drawn from painting!), a patient can choose, especially if that individual has difficulty articulating what type of pain is being experienced. Anamnesis, the technical term for taking a preliminary case history, derives from the Greek that means "easily recalled", though a urologist I know emphasized that pain reported by patients requires a great deal of questioning, and is precisely what is difficult to evoke during anamnesis. In the process of communicating, patient and doctor cooperate in characterizing the sensation and move forward toward a diagnosis mirrored in the titles of commonly used handbooks such as "from symptom to diagnosis". ${ }^{34}$ In working with sick children, additional communicative options have been developed, such as scales of smiley-faces turning increasingly grim. Some patients are very competent in describing pain as burning, cutting, dull, drilling, and so forth, and can readily relate their own observations of its development. An attack of appendicitis, for instance, will start with a dull pain around the navel, changing to acute, stinging pains in the right lower belly. While some patients already signal this potential diagnosis through the body posture in which they enter the emergency ward, with others it is necessary to elucidate the spectrum from "merely" physical pain to pain accompanied by strong emotional states, such as the enormous fear accompanying heart pains - a realm into which David Hufford's phenomenology of "the old hag" guided folklorists already 25 years ago (Hufford 1982). In Hufford's case study one notes again a traditionalization of a sensory phenomenon, with "the old hag" and associated narratives of "her" attacks offering a visual image for the coupled unfolding of fear and pain. Philosopher Nikola Grahek in his Feeling Pain and Being in Pain (2001) worked through reports in the medical literature

33 Personal communication, February 26, 2006.

34 A classic work still used among my medical acquaintances is Hadorn (1960); an American text that has been translated into several languages is Johnson, Greene and Maricic (1993). 
describing aberrant cases of pain - patients who did not feel pain when they should have and as a result physically harmed themselves inadvertently (the term for this is pain-asymbolia). Grakeh argued that what was lacking in these individuals was not only an element within the nervous system - but also an attendant cultural capacity to process pain sensations appropriately.

The skill in verbalizing sensual experience was exemplified here quite superficially, using Western medical practice as an example. Medical anthropologist Elizabeth Hsu has done so competently with forms of acute pain therapy in traditional Chinese medicine (Hsu 2005). She has, however, also been interested in exploring the linkage between individual and collective in the experience and treatment of pain (Hsu 1993/94), arguing that pain management regimes in Western medical practice seek to minimize pain chemically, mirroring a general societal effort to make pain and suffering invisible (2005: 92-93). ${ }^{35}$

Enabling sensual experience and expression is then as much a professional as an interpersonal skill. One must assume that in most crafts, controlled sensual experience has to be acquired and limited in order to achieve a result both functional and aesthetically pleasing - for instance, the right feel of clay to be worked on the potter's wheel; the colour that metal of the appropriate heat would show to be worked on by a smith. But a great deal of sensory knowledge is used professionally without requiring verbalization. Cristina Grasseni (2004) has written about what she terms "skilled vision" among alpine cow breeders who rely on their critical vision in breeding decisions in order to achieve the aesthetic ideal of their community. Animal-human relationships may in general challenge and/or bring forth human capacity for harnessing sensual skills. ${ }^{36}$ One of my students, Jennifer Rovanpera, proposed for instance that learning how to ride a horse could be described as "training your body in touch" - a component one might include across a variety of sports: the sense of touch as well as balance assists in developing and guiding the muscular control required to execute a pirouette or make it across a steep slope on skis. An equestrian sport such as dressage requires extensive learning on the part of beginners "to teach their own bodies how to 'feel' the horse before they can advance to manipulate the horse's movements. Feeling the horse involves the whole body: the hands and legs feel the horse's balance, straightness and direction; the rider's seat feels how relaxed the horse is; all the way through the back and spine the rider feels how much spring and energy the horse has in his step" (Rovanpera 2006). The capacity for this kind of feeling, for training the body in touch, varies enormously. Even a brief afternoon of participant

35 This would be in contrast to the lust-torture complex alluded to above which remains in the nonor secretly verbalized realm.

36 Jay Mechling (1989) has contemplated animal-human dyadic play in his memorable essay "Banana canon". 
observation at a riding school will demonstrate how some neophytes will take to what Rovanpera describes with ease and glee, uncovering in their first hours on a horse a whole set of coordination skills and flexibility that had slumbered in their bodies. For others there is the voice of the patient or increasingly exasperated riding teacher who hollers across the rink "Sit up straight! Relax the shoulders! Don't lean forward! Use your thighs!" The instruction is to enable the correct movements, overcoming the cerebral control, so as to develop the proper sensory experience and ultimately control the animal in an embodied rather than exclusively cerebral fashion.

\section{CONCLUDING THOUGHTS}

A challenge inherent to any work with the senses remains the question where one might best stop. It surely is not an accident that we cannot point to a long list of anthropological or folkloristic studies on pleasure, or, for that matter, pain. Indeed, even within the burgeoning anthropology of the senses, and the various new readers on the different senses, one finds little that directly addresses realms that are seemingly cordoned off as too intimate. One of the few, and first, is Steven Feld's Sound and Sentiment (1982) which allowed us to appreciate - in at the time novel ways - where sorrow and pain resided among the Kaluli and how such sentiments were aesthetically elaborated to increase the pleasure of that sorrow. An exploration of the sensorium's workings in embodied human experience perhaps pushes things to a more concrete level than what The Anthropology of Experience (Turner and Bruner 1986) suggested. In his recent meditation on "Sensing nature: encountering the eworld in hunting", Garry Marvin sought to communicate, first and foremost, the mode of engagement with the world as it is experienced by hunters. While he is aware of the social and cultural meanings of different types of hunting, Marvin seeks to bring out what matters, "being in a state of heightened awareness of, and intensely attuned and responsive to, the places in which they hunt" - an "emotional intensity" owed to the fact that hunters are not spectators of nature, but that their "special engagement with the natural world" comes from "being prepared at any moment to kill" (2005: 23). For understanding "hunting as a cultural practice in all its complexity", Marvin argues, he first has to find "a way to pay attention to these multi-sensual ways of experiencing the world. Hunting does not just mean something to hunters, it is something they do" (2005: 24-25, my italics).

The last sentence encapsulates the connection that my circuitous exploration aims for. Attention to the senses, how we experience them, how we are told to handle them through various regimes we inhabit or pass through, adds to scholarship focused on performance and agency a dimension of embodied life in which frames of meaning and enactment can come together. Sensory 
dimensions are what make life bearable or unbearable, pleasant or exhilarating, and turning to them is surely appropriate for fields seeking to understand individuals charting their life course within and between culturally circumscribed groups. The safest ground to study them very likely remains in the realm of the verbalized that can be occasionally documented in context.

Crucial for the development of such a research realm is the development of methods and in particular methodological mixing. Incorporating - and not isolating - the cultural workings of the sensorium in ethnographic, historical and literary research requires methodological adjustments that might give the field a deepened groove to work its magic.

How to represent the results of such methodological adjustments is the final question to be posed. As happened to most everyone who has rediscovered the senses as an area of cultural research, this forces one to examine the slow vanishing of the senses in the history of our fields, demonstrated for instance by Nélia Dias in her study of French anthropology (2004). The disciplining of universalist scholarship, in the course of the $19^{\text {th }}$ century, not only brought forth bounded fields of research. It also established sensory hierarchies that bolstered scholarly legitimation. The organization of knowledge production has privileged particular variants of hearing (as in teaching and presentation) and seeing (reading and variants of seeing coupled with scientific tasks), a development that has ultimately lead not only to the marginalization of the full sensorium in acceptable scholarship but also in considering the sense's role in cultural practice and human existence. David Howes as one of the leading scholars championing the sensual turn, reflects on these issues and concludes that translating sensual insight into writing remains the most effective form of representation (2003: 58). Perhaps, though, our tired eyes and ears would welcome a bit of a revolution in the production of legitimate scholarly knowledge as well.

\section{ACKNOWLEDGMENTS}

This paper has benefited from the critical and collegial comments of Johannes Fabian, Lee Haring, Dorothee Hemme, Valdimar Hafstein and Deborah Kapchan as well as from the lively discussions after its initial presentation as a lecture in honor of Alan Dundes at UC Berkeley and the subsequent settings where I was invited to present versions of it. For the invitation to prepare these thoughts initially, I thank Charles Briggs, for further invitations to talk on this topic, I thank Laura Stark at the University of Jyväskylä in Finland, Maria Cardeira da Silva and Clara Saraiva of the Nova University in Lisbon, Portugal, and Ellen Gray and Ana M. Ochoa of Columbia University, New York, USA. Thanks also go to Rudolf and Monika Flückiger who offered evidence and references from the realm of Western medical practice. 


\section{REFERENCES}

ABRAHAMS, Roger D., 2005, A Poetics of Everyday Life. Philadelphia: University of Pennsylvania Press.

ABU-LUGHOD, Lila, and Catherine A. LUTZ, 1990, "Introduction", in Catherine A. Lutz and Lila Abu-Lughod (eds.), Language and the Politics of Emotion. Cambridge: Cambridge University Press, 1-23.

ARMStrong, Robert Plant, 1971, The Affecting Presence: An Essay in Humanistic Anthropology. Urbana: University of Illinois Press.

BAUMAN, Richard, 1971, "Differential identity and the social base of folklore", Journal of American Folklore, 84: 31-41.

BAUMGARTEN, Alexander G., 1983 [1750-58], Texte zur Grundlegung der Aesthetik. Edited and translated from the original Latin by Hans Rudolf Schweizer. Frankfurt: Felix Meiner Verlag.

BENDIX, Regina, 2000, "The pleasures of the ear: towards an ethnography of listening", Cultural Analysis, 2000 (1): 33-50. Available at < http://ist-socrates.berkeley.edu/ cafor um/volumel/voll_article3.html > (last access June 2021).

BENDIX, Regina, 2004, "Rezeption", Enzyklopädie des Märchens. Berlin: De Gruyter, 2004 (11): 626-633.

BENDIX, Regina, 2005a, “The cream effect”, Ethnologia Europaea, 35 (1-2): 14-18.

BENDIX, Regina, 2005b, "Stimme: Eine Spurensuche", in Thomas Hengartner and Brigitta Schmidt-Lauber (eds.), Leben-Erzählen. Beiträge zur Biographie- und Erzählforschung. Berlin: Reimer, 7 1-95.

BENDIX, Regina, 2006, "Was über das Auge hinausgeht - Zur Rolle der Sinne in der ethnographischen Forschung”, Schweizerisches Archiv für Volkskunde, 102: 71-84.

BOURDIEU, Pierre, 1984, Distinction. (Translation by R. Nice) Cambridge, MA: Harvard University Press.

BRENNEIS, Don, 2005, "Afterword: sense, sentiment, and sociality", Etnofoor, 18 (1): 142-149. BRONNER, Simon, 1982, “The haptic experience of culture”, Anthropos, 77: 351-352.

BRONNER, Simon, 1986, Grasping Things: Folk Material Culture and Mass Society. Lexington: University Press of Kentucky.

BulL, Michael, 2000, Sounding out the City: Personal Stereos and the Managing of Everyday Life. New York: Berg Publishers.

CLASSEN, Constance, 1991, "Literacy as anti-culture: the Andean experience of the written word”, History of Religions, 30 (4): 404-421.

CLIFFORD, James, 1986, "Introduction: partial truth", in James Clifford and George Marcus (eds.), Writing Culture: The Poetics and Politics of Ethnography. Berkeley: University of California Press, 1-26

DIAS, Nélia, 2004, La mesure des sens: les anthropologues et le corps humain au XIXe siècle. Paris: Editions Flammarion.

DUNDES, Alan, $1971 \mathrm{a}$, "Thinking ahead: a folkloristic reflection of the future orientation in American world view", Anthropological Quarterly, 42: 53-71.

DUNDES, Alan, 197 lb, "Folk ideas as units of world view", Journal of American Folklore, 84: 93-103.

DUNDES, Alan, 1980a [1972], "Seeing is believing", in Alan Dundes, Interpreting Folklore. Bloomington: Indiana University Press, 86-92. 
DUNDES, Alan, 1980b [1977], "Who are the folk?", in Alan Dundes, Interpreting Folklore. Bloomington: Indiana University Press, 1-19.

DUNDES, Alan, 1980c, Interpreting Folklore. Bloomington: Indiana University Press.

DUNDES, Alan, 1985, "Nationalistic inferiority complexes and the fabrication of fakelore: reconsideration of Ossian, the Kinder - und Hausmärchen, the Kalevala and Paul Bunyan", Journal of Folklore Research, 22: 5-18.

FELD, Steven, 1982, Sound and Sentiment: Birds, Weeping, and Song in Kaluli Expression. Philadelphia: University of Pennsylvania Press.

FELDMAN, Jackie, 2008, Above the Death-Pits, beneath the Flag: Youth Voyages to Poland and the Performance of Israeli National Identity. Oxford: Berghahn.

FOUCAUlT, Michel, 1991, Der Wille zum Wissen. Sexualität und Wahrheit 1. Frankfurt am Main: Suhrkamp.

GRABURN, Nelson, 2001, "Learning to consume: what is heritage and when is it traditional?”, in Al Sayya (ed.), Consuming Tradition, Manufacturing Heritage. New York: Global Norms and Urban Forms in the Age of Tourism, 68-89.

GRAHEK, Nikola, 2001, Feeling Pain and Being in Pain. Oldenburg: Bibliotheks - und Informationssystem der Universität.

GRASSENI, Cristina, 2004, "Skilled vision: an apprenticeship in breeding aesthetics", Social Anthropology, 12 (1): 1-15.

HADORN, Walter, 1960, Vom Symptom zur Diagnose: Lehrbuch der medizinischen Symptomatologie. Basel: Karger.

HALL, Edward T., 1959, The Silent Language. Garden City: Doubleday.

HEMME, Dorothee, 2008, "Harnessing daydreams: a library of fragrant fantasies", paper delivered at the $9^{\text {th }}$ SIEF Congress in Derry, Northern Ireland, June 17th.

HERZFELD, Michael, 1997, Cultural Intimacy: Social Poetics in the Nation-State. New York: Routledge.

HERZFELD, Michael, 2002, Anthropology: Theoretical Practice in Culture and Society. Oxford: Blackwell.

HOWES, David (ed.), 1991, The Varieties of Sensory Experience: A Sourcebook in the Anthropology of the Senses. Toronto: University of Toronto Press.

HOWES, David, 2003, Sensual Relations: Engaging the Senses in Culture and Theory. Ann Arbor, MI: University of Michigan Press.

HOWES, David (ed.), 2005, Empire of the Senses: The Sensual Culture Reader. Oxford: Berg. HSU, Elisabeth, 2005, "Acute pain infliction as therapy", Etnofoor, 18 (1): 78-96.

HSU, Elisabeth, 1993/94, "Schmerz, Individuum und Gemeinschaft", in Marc-Olivier Gonseth (ed.), Les Frontières du Mal: 5 Approches Anthropologiques de la Santé et la Maladie. Ethnologica Helvetica, 17/18: 65-74.

HUFFORD, David, 1982, The Terror that Comes at Night: An Experience-Centered Study of Supernatural Assault Tradition. Philadelphia: University of Pennsylvania Press.

JANSEN, William H., 1959, "The esoteric-exoteric factor in folklore", Fabula, 2: 205-211 .

JAY, Martin, 1994, "The disenchantment of the eye: surrealism and the crisis of ocularcentrims", in Lucien Taylor, Visualizing Theory: Selected Essays from Visual Anthropology Review. New York: Routledge, 173-201.

JOHNSON, William P., Harry L. GREENE, and Michael J. MARICIC (eds.), 1993, Decision Making in Medicine. New York: C. V. Mosby. 
KAMPER, D., and Christoph WULF (eds.), 1984, Das Schwinden der Sinne. Frankfurt: Suhrkamp.

KANAANA, Sharif, 2005, "The Arab ear and the American eye: a study of the role of the senses in culture" (Translation by Ibrahim Muhawi) Cultural Analysis, 4 (2005): 29-45. Available at < https://www.ocf.berkeley.edu/ culturalanalysis/volume4/pdf/kanaana. pdf $>$ (last access June 2021).

KÖSTLIN, Konrad, 1995, "Lust aufs Ganze: Die gedeutete Moderne: Oder die Moderne als Deutung - Volkskulturforschung in der Moderne", Österreichische Zeitschrift für Volkskunde, 49: 255-275.

LAU, Kimberly J., 2000, New Age Capitalism: Making Money East of Eden. Philadelphia: University of Pennsylvania Press.

LEHRER, Adrienne, 1983, Wine and Conversation. Bloomington: Indiana University Press.

LENNON, John J., and Malcolm FOLEY, 2000, Dark Tourism. London: Continuum.

LIBERMAN, Mark, 2004a, "Ritual Verbal Enthusiasm for Food". Available at < http://itre.ci s.upenn.edu/ myl/languagelog/archives/000880.html > (last access June 202 l)

LIBERMAN, Mark, 2004b, "More on winetalk culture". Available at < http://itre.cis.upenn. edu/ myl/languagelog/archives/001005.html > (last access June 2021).

MARVIN, Garry, 2005, "Sensing nature: encounter the world in hunting", Etnofoor, 18 (1): $15-26$.

MECHLING, Jay, 1989, “'Banana Canon' and other folk traditions between human and nonhuman animals", Western Folklore, 48: 312-23.

METRAUX, Rhoda, 1953, "Resonance in imagery", in Margaret Mead and Rhoda Métraux (eds.), The Study of Culture at a Distance. Chicago, University of Chicago, 343-362.

MOERAN, Brian, 2005, "Japanese fragrance descriptives and gender constructions: preliminary steps towards an anthropology of olfaction", Etnofoor, 18 (1): 97-125.

NAUMANN-BEYER, Waltraud, 2003, Anatomie der Sinne im Spiegel von Philosophie, Ästhetik, Literatur. Vienna: Böhlau.

OGOURA, Kazuo, 2004, Dégustations du vin a travers la littérature française. Versailles: Mémoire \& Documents.

OPASCHOWSKI, Horst W., 1991, Mythos Urlaub. Die unerfüllte Sehnsucht nach dem Paradies. Eine motivationspyschologische Studie. Hamburg: BAT-Freizeit-Forschungsinstitut.

OPASCHOWSKI, Horst W., 1993, Freizeit und Lebensqualität. Perspektiven für Deutschland. Hamburg: BAT-Freizeit-Forschungsinstitut.

PICARD, David, 201 1, Tourism, Magic and Modernity: Cultivating the Human Garden. Oxford: Berghahn.

PRATT, Mary L., 1992, Imperial Eyes: Travel Writing and Transculturation. New York: Routledge. RÖTTGER-RÖSSLER, Birgitt, 2002, "Emotion und Kultur: Einige Grundfragen”, Zeitschrift für Ethnologie, 127: 147-162.

RÖTTGER-RÖSSLER, Birgitt, 2004, Die kulturelle Modellierung des Gefühls: Ein Beitrag zur Theorie und Methodik ethnologischer Emotionsforschung anhand indonesischer Fallstudien. Münster: LIT.

ROVANPERA, Jennifer, 2006, research proposal for the seminar "Anthropology and Ethnography of the Senses", winter semester 2005-06. Göttingen: Institute for Cultural Anthropology/European Ethnology.

SCHMIDT-LAUBER, Brigitta, 2004, "Grenzen der Narratologie. Alltagskulturforschung jenseits des Erzählens”, in Thomas Hengartner and Brigitta Schmidt-Lauber (eds.), Leben - Erzählen. Beiträge zur Erzähl- und Biographieforschung. Berlin: Reimer, 145-164. 
SCHREMPP, Gregory, 1996, "Dimensions of worldview: Worldview as an organizing concept in ethnographic and narrative research", in Leander Petzoldt, Folk Narrative and World View. Vorträge des 10. Kongresses der ISFNR Innsbruck [1992], part 1. Bern, Peter Lang, 21-31.

SILVERSTEIN, Michael, 2003, "Indexical order and the dialectics of sociolinguistic life", Language and Communication, 23 (3): 193-229.

SILVERSTEIN, Michael, 2004, "Cultural' concepts and the language-culture nexus", Current Anthropology, 45 (5): 621-652.

SILVERSTEIN, Michael, 2006, "Old wine: New ethnographic lexicography", Annual Review of Anthropology, 15: 481-96.

SKINNER, Jonathan (ed.), 2012, Writing the Dark Side of Travel. Oxford: Berghahn.

SKLAR, Deirdre, 1994, "Can bodylore be brought to its senses?", Journal of American Folklore, 107 (423): 9-22.

SKLAR, Deirdre, 2005, "The footfall of words: a reverie on walking with nuestra señora de Guadalupe", Journal of American Folklore, 118 (467): 9-20.

STAGL, Justin, 2006, A History of Curiosity: The Theory of Travel 1550-1800. London: Routledge (German original: 2002, Eine Geschichte der Neugier: Die Kunst des Reisens 1550-1800. Vienna: Böhlau).

STRANG, Veronica, 2005, "Common senses: water, sensory experience, and the generation of meaning”, Journal of Material Culture, 10 (1): 92-120.

STURM, Brian, 2002, "Lost in a story", in Irene Maria F. Blayer and Monica Sanchez, Storytelling: Interdisciplinary and Intercultural Perspectives. New York: Peter Lang Inc., 14-26.

TAYLOR, Charles, 1989, Sources of the Self: The Making of the Modern Identity. Cambridge, MA: Harvard University Press.

TURNER, Mark, 1996, The Literary Mind: The Origins of Thought and Language. Oxford: Oxford University Press.

TURNER, Victor, and Jerome BRUNER (eds.), 1986, The Anthropology of Experience. Urbana, $\mathrm{OH}$ : University of Illinois Press.

ULIN, Robert C., 1995, "Invention and representation as cultural capital: Southwest French winegrowing history”, American Anthropologist, 97 (3): 519-527.

URRY, John, 1990, The Tourist Gaze: Leisure and Travel in Contemporary Societies. London: Sage.

WANDER, Karl Friedrich, 2001 [1867-1880], Deutsches Sprichwörter-Lexikon, [CD-Rom]. Berlin: Directmedia.

WULFF, Helena (ed.), 2007, The Emotions: A Cultural Reader. London: Berg.

YANKAH, Kwesi, 1989, Proverbs in the Context of Akan Rhetoric. Bern: Peter Lang. 